\title{
Improving English Majored-Students' Learning Outcomes via the Inclusion of Entrepreneurship Education and Training at the Tertiary Level in Vietnam
}

\author{
Chu Quang Phe \\ University of Finance - Marketing \\ cq.phe@ufm.edu.vn
}

\begin{abstract}
This paper centers on exploring the trend and practice of including entrepreneurship education and training (hereinafter called EET) in the higher education curriculum in the world. Its author also supports the idea that entrepreneurship can be learnt through EET programs under certain circumstances. After examining the true condition of Vietnam for private entrepreneurs since it became independent in 1945, his analysis shows that Vietnam is the prospective market not only for domestic business people but also for foreign investors. Then, he highly recommends some proper measures for Vietnamese universities and colleges to introduce EET programs to English-majored students formally. It is supposed that the inclusion of EET programs at the tertiary level not only helps minimize the unemployment rate among new graduates on the present-day labor market but also contributes to generating jobs for others.
\end{abstract}

Keywords: entrepreneurship; intrapreneurs; micropreneurs; entrepreneurship; education and training; enterprise; start-up; graduate; incubator; enterprise zone; mindsets

\section{Introduction}

Entrepreneurship has long existed and is the most powerful economic force known to humans (Certo \&Certo, 2009). The history of the 
United States is the history of entrepreneurs, (Nickels et al, 2012); besides, Greenfield and Strickson (1981) attached the role to the economic growth, creating business and fostering innovation, (cited in Hoang \& Dung, 2009). Although literature and practice have worked out that entrepreneurship is important in national economic development (Napier et al, 2012), it has just got researchers' interest for the last fifty to thirty years. Aware of its importance, universities and colleges, (hereinafter called universities) in various parts of the world have introduced EET to equip their students with certain knowledge and skills and nurture their aspiration to become entrepreneurs, the active part of a business generating jobs rather than the passive one (Wilson, 2008).

In Vietnam, many universities have been granted permission to offer BA degrees in English, English Studies, Teacher Education in English, English Linguistics and Literature, English Translating and Interpreting, Business-oriented English (hereinafter called English). They conventionally effort to help their undergraduates master a certain amount of skills and knowledge in their major and for some universities, they offer job-seeking skills as extra-curricular courses; thus, entrepreneurship is still excluded from the curriculum. Though the need for recruiting graduates of English is still growing, especially at the period of international integration, the labor market has become more selective and even choosy, and seeking an appropriate job turns out to be much more competitive than ever; thus, a creative and proactive graduate might be wise to choose to enter into entrepreneurship.

As a result, this paper reviews various scientific works on EET programs, especially at the tertiary level. Then, the author discusses the specific conditions in Vietnam for new graduates in general and English majored-students in particular to become entrepreneurs. Finally, he proposes some recommendations for universities to put into consideration in the hope that they can take advantage of EET.

\section{Entrepreneurial Opportunities in Vietnam}

After President Ho Chi Minh read the Independence Declaration on September $2^{\text {nd }}, 1945$ to give birth to the People's Democratic Republic of Vietnam, currently known as the Socialist Republic of Vietnam (hereinafter called Vietnam), the centrally planned economic model 
prevailed for a long time. Despite the fact that Vietnam was faced with difficulties such as War of National Reunification (1954-1975), Cambodian-Vietnamese Border War with the Khmer (1977-1979) and Chinese-Vietnamese Border War (1979-1990), some big economic reforms such as Land Reforms (1956-1958), Collectivization of Farms (1959-1970), or Rehabilitation of Private Industries and Trade (19641975) were still introduced to reinforce the dominance of the state economic sector and simultaneously eliminated illegally-recognized private ownership. During the time, entrepreneurship was kept from growing and developing, (Hoang \& Dung, 2009). However, 1986 was often considered by many as a turning point for Vietnam when the command economy was officially replaced after the $6^{\text {th }}$ Communist Party Congress introduced the Reform or Đổi Mới. According to Hoang and Dung (2009), this "revived the private sector economy and hence encouraged private capital investments in legally recognized private entrepreneurial operations.

Then, on the way towards international integration, after normalizing the diplomatic relation with the USA in 1995, especially with the embargo on foreign trade lifted, and joining the World Trade Organization (WTO) in 2006, the Association of Southeast Asian Nations (ASEAN) in 1995, Asia-Pacific Economic Cooperation (APEC) in 1998, Asia-Europe Meeting (ASEM) in 1997, ASEAN Economic Community (AEC) in 2015, and Trans-Pacific Strategic Economic Partnership Agreement (TTP) in 2016, Vietnam not only has recognized and helped the private sector grow and develop but also has attracted more foreign development investments (FDI). The centrally planned economy was replaced by market-oriented one, liberalizing the workforce and making most out of its creativity. In fact, Vietnam is proceeding closer to developed countries, taking advantage of their advances in almost all the domains and becoming a cosmopolitan labor market for FDI, which speeds the generation of jobs and wealth for its residents.

The Reform has proven to be the right way for Vietnam to get out of poverty, obsolescence, and red-tape and has changed the structure of its society. It has brought about the phenomenal transition to a marketdriven model. Thanks to the international cooperation and effective reforms, Vietnam had 488.148 businesses (updated on January 31, 2015), over $95 \%$ of which are legally recognized as small- and 
medium- sized enterprises ${ }^{1}$. Numerous as they might be, Vũ Tiến Lộc, Chairman of Vietnam Chamber of Commerce and Industry stressed that for privately-owned businesses to grow and develop in the international integration, Vietnam needs an entrepreneurial revolution with the objective of starting up five million enterprises, tenfold compared to the existing number of operational ones ${ }^{2}$. The government of Vietnam also issued a lot of documents on facilitating enterprises, especially start-ups and Vietnam is arousing national entrepreneurial spirits for businesses or individuals ${ }^{3}$. Deputy Prime Minister Vũ Đức Đam also reveals that the government always generates favorable conditions for start-ups in order that entrepreneurship can spread nationwide ${ }^{4}$. As a result, entrepreneurship is quite prospective in Vietnam currently not only for domestic business people but also for foreign investors, especially when it has a population of over 90 million, many of whom wish to be rich in a fast growing economy (Napier et al, 2012).

\section{Entrepreneurship Education and Training}

\section{Entrepreneurship}

There is growing interest in the role that entrepreneurship can play as a catalyst to achieve economic and social objectives, including innovation, employment, growth and equity (Valerio et al, 2014, p.11). The United States, Canada, and New Zealand have passed acts which offers priority to those prospective entrepreneurs who want to get their visas or permanent residence. The United States Immigration Act passed in 1990 created a category of "investor visas" because many people believe that the more entrepreneurs come, the more jobs will be created and the more the economy will grow (Nickels et al, 2012). Scholarly, there has been a great amount of literature on entrepreneurship discussed by various authors in economics, sociology anthropology, business management and political science since the mid- $20^{\text {th }}$ century, especially Joseph Schumpeter who attached entrepreneurship to the progress of human society and economic growth (Hoang \& Dung, 2009). Below are different areas of literature on entrepreneurship suggested by different scholars.

\footnotetext{
${ }^{1}$ The Saigon Economic Times (Online), posted on March 5, 2015

${ }^{2}$ VN Express (Online), posted on October 4, 2015

${ }^{3}$ VGP News, posted on February 14, 2016

${ }^{4}$ VN Express (Online), posted on March 30, 2016
} 
Entrepreneurship is accepting the risk of starting and running a business (Nickels et al, 2012; Snell, 1999). This risk taking is an attribute of entrepreneurs and they take moderate, calculated risks, not gambling, (Nickels et al, 2012). Besides the risks, entrepreneurs are also defined as those individuals who start a new business on identifying, evaluating and exploiting opportunities.

Nickels et al (2012) and Certo and Certo (2009) have contended that forming a new business would enjoy a greater chance of survival and success for entrepreneurial teams. Statistically, approximately $70 \%$ of new organizations are started by entrepreneurial teams (Certo \& Certo, 2009). The entrepreneurial firm is a particular type of organization that results from the entrepreneurship process, which could be either a totally new firm or the transformation of the existing organization (Stroke \& Wilson, 2010). In general, entrepreneurs normally take risks to seize opportunities to form a legally recognized enterprise.

Entrepreneurship is creating new products, either goods or services and is described as the process of discovery (Schumpeter 1934, cited in Valerio et al, 2014). To introduce new things, people need to be creative and innovative because "creativity is the ultimate resource for economic development" (Peters, 2009; as cited in Napier et al, 2012). During the entrepreneurial management, entrepreneurs must engage in specific management behaviors to drive the market or to produce innovation (Stroke and Wilson, 2010). Placing the emphasis on entrepreneurial creativity, Certo and Certo (2009) also describe entrepreneurs as those with their own ability to identify and exploit information pinpointing business opportunities that others fail to capitalize on.

Entrepreneurship is self-employment. Nickels et al (2012) point out that many people enjoy a greater extent of independence and freedom when working for themselves than working for others. Valerio et al cite that self-employment demands the differentiation between the incorporated self-employed (formed into an official company or organization with legal status) and the unincorporated self-employed (not formed into an official company or organization with legal status) (Rubinstein, 2013; ascited in Valerio et al, 2014). European Commission" asserts, "Entrepreneurial ventures are the major source of new jobs in the economy for the owner and new employees". 
Entrepreneurship is creating jobs. Enterprises can "serve as an important source of income and employment for vulnerable populations, and entrepreneurship is regarded as the largest source of new job growth in both developed and developing countries," (Birch 1979; as cited in Valerio et al, 2014). Fane (2012) also assumes that entrepreneurship give students more employability and Snell (1999, p.236) sees entrepreneurship as the act of forming a new organization of value.

Entrepreneurship is generating wealth. Certo and Certo (2009) refer it to the identification, evaluation and exploitation of opportunities. The framework of entrepreneurial opportunities involves "the occasions to bring into existence new products and services that allow outputs to be sold at a price greater than their cost of production" (Certo \& Certo, 2009, p.139). Nickels et al (2012) also assert that profit is an important reason for people to become entrepreneurs.

Entrepreneurship is changing the social structure. Greenfield and Strickon (1981, cited in Napier et al, 2012) and Klein (1982) view it as the mechanism by means of which society at one stage was transformed to another. To continue praising its role, Baumol (1990; as cited in Napier et al 2012) recommends that society should think, act and operate entrepreneurially. Klapper and Richmond (2009) underline the importance of entrepreneurship in contributing to the employment, spillovers, and structural economic change (Valerio et al, 2014). Habaradas (2009) also suggests that small and medium sized enterprises are seen as the means of reducing poverty, broadening and deepening the industrial structure. Hills (1994) defines entrepreneurship as a process that causes change in the economic system through innovation to create values for both individuals and society (Paswan \& Trang, 2011).

Entrepreneurship not only leads to the formation of start-ups where individuals or teams see opportunities but also may trigger a contagion in well-established enterprises, (Ahuja \& Lampert, 2001; McDougall \& Oviatt, 2000; as cited in Napier et al, 2012, Stroke \& Wilson, 2010). These entrepreneurs are often called intrapreneurs ${ }^{5}$ and their idea is to utilize a company's existing resources to launch a new product or generate profits, (Nickels et al, 2012). Another form of

\footnotetext{
${ }^{5}$ Creative people who work as entrepreneurs within corporations
} 
entrepreneurship may involve micropreneurs who are willing to accept the risk of starting and managing a business that remains small. Most micropreneurs are home-based businesses, offering their owners a balanced lifestyle while doing what they want to do.

In the light of Vietnam's private entrepreneurship, it represents an important fabric of society and it has been contributing a lot to the country's transitional economy. Prior to the Reform (1986), the dominance of the state economic sector, including state-owned enterprises and collectives, led the national economy and the privately owned sector existed illegally in forms of self-employed households and small businesses. In other words, private entrepreneurship was not permitted by law (Bich et al, 2007).

After the Reform, the law has recognized the private sector where the multi-sector economy was chosen as the roadmap for the country's economic growth and development though there were discriminations in terms of access to land, capital, technology, training, and so on, (Bich et al, 2007). However, Hoang and Dung (2009) point out that entrepreneurship as the most important driver of the omnipresent growth of the economy, and in fact, it has become a universal attempt and spirits among thousands of people wishing to be rich (Hoang and Dung, 2009). More promisingly, the results of Swiek et al's (2003) research find out that the Vietnamese have a higher level of risk-taking than Thais and Thang's research (2009) also indicates that the Vietnamese have higher score in their intention to start up a business than the USA and Taiwanese and are more confident in creating a new venture than the Taiwanese. Consequently, entrepreneurship not only realizes many Vietnamese people's dreams to get rich but also is the only way out to deal with the high unemployment rate resulting from the influx of new graduates every year and helps compete with foreign enterprises.

\section{Entrepreneurship Education and Training}

EET "represents academic education or formal training interventions that share the broad objective of providing individuals with the entrepreneurial mindsets and skills to support participation or performance in a range of entrepreneurial activities", (Valerio et al, 2014, p.21). 
Over the last twenty years, EET programs to promote entrepreneurial skills and attitudes have been growing great interest worldwide although people doubt whether mindsets and skills are cultivated, taught or transmitted for the purpose of entrepreneurship promotion. Akola and Heinonen (2006) distinguish the art and the science of entrepreneurship, in which the latter is not teachable, except through the practical experiences while the latter can be learnt, (Valerio et al, 2014; Wilson, 2008). Furthermore, Europe Commission claims "Entrepreneurs are not born... they "become" through the experiences in their life." Regarding this point, the author supports Valerio who suggests that "when the education and training system incorporates creative and entrepreneurial skills into teaching methodologies, mindsets and skills more closely tied to the art of entrepreneurship are transmittable".

Valerio et al (2014) also effort to differentiate entrepreneurship education from entrepreneurship training by the program objectives and outcomes as below.

Entrepreneurship education (EE) programs tend to focus on building knowledge and skills for the purpose of entrepreneurship. Due to the academic nature of EE, these programs mostly target students from secondary education to higher education (Valerio et al, 2014) as illustrated in Figure 1. Education plays an important part in shaping attitudes, skills, and culture, from the primary level up and EE offers a mix of experiential learning, skill building and mindset change (Wilson, 2008). More importantly, European Commission stresses that EE serves as inspiring entrepreneurial potential where people need the mind-set, skills and knowledge to generate creative ideas, and the entrepreneurial initiative to turn those ideas into action.

Entrepreneurship training (ET) programs tend to centre on building the knowledge and skills, explicitly in preparation for starting or operating a new venture. ET programs mainly target a wide number of potential and practicing entrepreneurs, (Valerio et al, 2014) as illustrated in Figure 1. Also, European Commission adds that after adults have got job experience or have furthered their education, many of them are in need of special assistance to assemble business ideas through education programs on start-ups. 


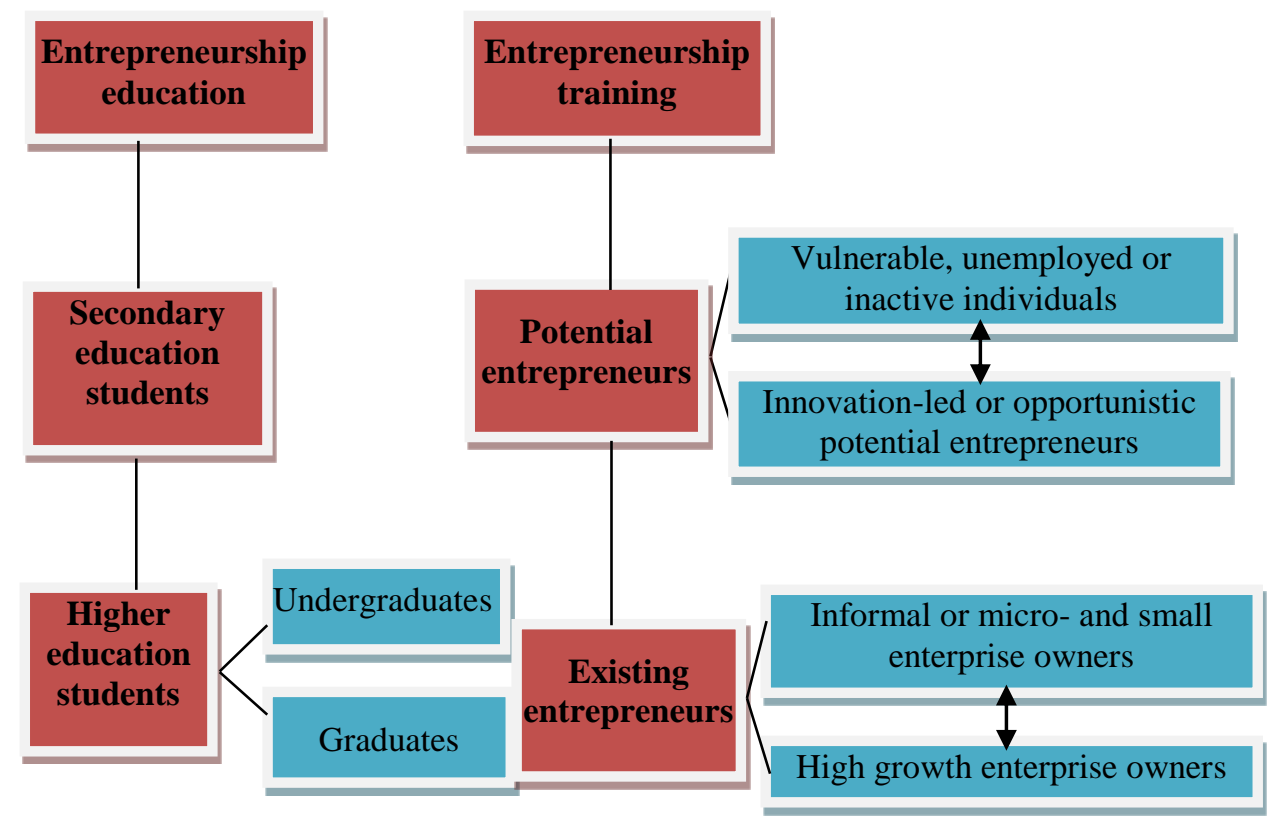

Figure 1. Classifying EE and ET (Valerio et al, 2014)

Even though the two categories of EE and ET are distinguished upon the group of audiences they tend to target, they are often combined and balanced in various interventions, from formal academic education to stand-alone training programs.

\section{Conceptual Framework of EET}

On choosing an EET program, course designers usually take into consideration of its objectives and target audiences. Valerio et al (2014) use the conceptual framework to categorize EET program outcomes into a series of four major domains as below.

Entrepreneurial mindsets refer to the socio-emotional skills and overall awareness of entrepreneurship associated with entrepreneurial motivation and future success as an entrepreneur (e.g., self-confidence, leadership, creativity, risk propensity, motivation, resilience, and selfefficacy).

Entrepreneurial capabilities refer to entrepreneurs' competencies, knowledge, and technical skills associated with their entrepreneurship (e.g., management skills, accounting, marketing, and technical knowledge). 
Entrepreneurial status refers to the temporal state of a program beneficiary as measured through entrepreneurial activities and beyond (e.g., starting a business, becoming employed, and achieving a higher income).

Entrepreneurial performance refers explicitly to how indicators of a venture's performance have changed as a result of an intervention (e.g., higher profits, increased sales, greater employment of others, higher survival rates).

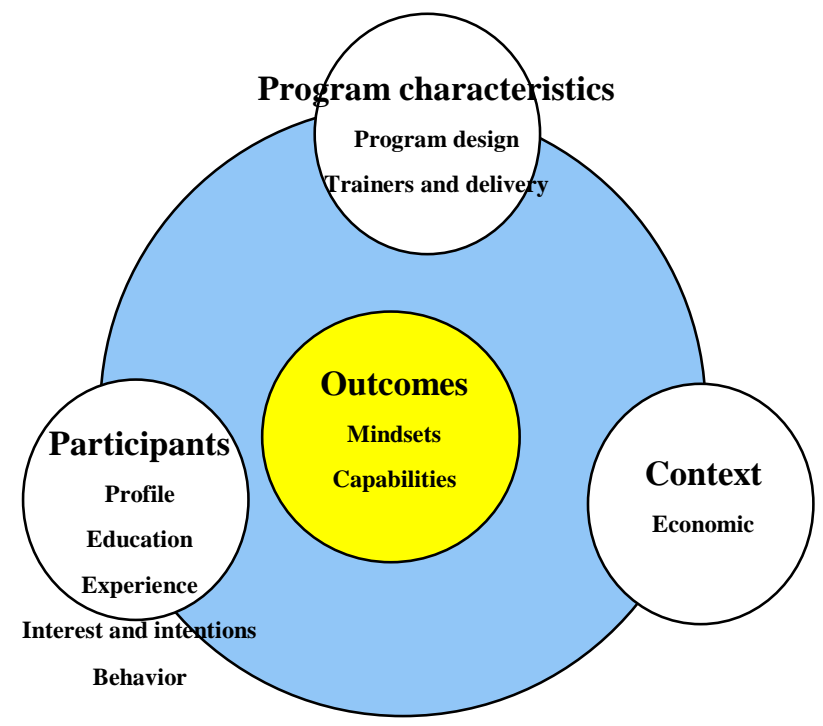

Figure 2. The conceptual framework (Valerio et al, 2014)

Examining ten EET programs for higher education students, Valerio et al (2014) find out that there is a relationship between entrepreneurship outcomes and academic-focused EET interventions. They evaluated the impact of two out of the ten EET programs on the audiences' outcomes, both evaluations provide compelling results for the capacity to foster positive effects in mindsets capabilities but provide mixed results around entrepreneurial status. The evaluation of the other programs also indicates the promising results in mindsets and capabilities.

\section{Recommendations on EET for English-majored Students}

As can be seen on many universities' websites throughout the country, holding a BA in the English language is still appealing to high school 
students; consequently, admission is very competitive. Besides, graduates of English are vaguely advised to do multi-disciplinary jobs such as executive workers in finance, tourism, hospitality, diplomacy, import, expert, business management, marketing, events management, translation, interpretation, international journalism, and publishing houses; clerks or assistants at meetings, conferences, and economic groups; or teachers of English from the primary level up. However, it is clear that universities are training their students to do certain jobs, becoming the passive part of an organization. Wilson (2008) has pointed that training students for a career is not enough in the presentday time; indeed, it is time for universities to get their students prepared to work in a dynamic, rapidly changing, entrepreneurial environment or become entrepreneurs. Fane (2012) when exploring entrepreneurial opportunities for students studying abroad argues that understanding foreign languages and having intercultural skills are crucial factors in achieving their competency, which is considered as a very desirable skill for global business leaders. Her encouragement is that if one discovers that one has an aptitude for and enjoys language learning, it is worth considering an entrepreneurial career that takes advantage of one's language skills such as starting up a language school, a tourism agency, or a translating and interpreting business. As a result, jobseeking skills should be supplemented with entrepreneurship skills at universities and below are some recommendations to increase Englishmajored students' learning outcomes via the inclusion of EET.

Universities should offer English-majored students EET programs either as extracurricular courses, perhaps certificate-granting ones, or part of the curriculum with the inclusion of all the four domains of outcomes as mentioned earlier. EE and ET programs should be balanced, depending on participants' characteristics. Therefore, to make them participantdriven courses, the more progress the students make, the more ET programs they should be given. The group of trainers should consist successful businesspersons or professors. Additionally, the courses should involve students from different disciplines in order that can draw upon the expertise from across the university. When the participants become creative and innovative, they can see entrepreneurial opportunities not only in their major but also in different areas. For 
example, Fane (2012) finds out that students with linguistic and intercultural skills have started up in various areas of business such as online networks for students, luxury travel websites, language services agencies, writing books, coffee businesses, and so on.

Universities should promote entrepreneurial culture/awareness among students since culture has a great impact on entrepreneurship, especially when strict Confucian values such as generational orders, hierarchy, paternalism, and loyalty tend to guide the majority of people in Vietnam (Hoang \& Dung, 2009). This not only hinders students' mindset change and learning of new things to be creative and innovative but also keeps them from reception of new skills. Thus, efforts are badly needed in order that entrepreneurial culture can be formed to promote entrepreneurial attempts and spirits.

EET should be closely linked to business practice. Universities can deploy case studies to inspire their students through each lesson where students can explore successful ventures and admire real-life business owners. In fact, students can develop their managerial skills in business management or new product ideas and concepts via valuating others' entrepreneurial situation in terms of strengths, weaknesses, opportunities and challenges before they might start up their own businesses.

Universities should form institutionally run clubs as the "enterprise zone $^{6 "}$ or incubator ${ }^{7}$ for potential entrepreneurs who are quite actionoriented. Great business ideas do not work; alternatively, they have to realize, actualize and build their dream in reality (Nickels et al, 2012). Accordingly, after students attend EET programs, universities should permit them to start and run small ventures, e.g. shopping stands, food counters or parking lots. Instead of subcontracting out these facilities and services, students should be allowed to trade in petty products such as stationeries, parking, junk food, publications, accessories, decors, or

\footnotetext{
${ }^{6}$ Specific geographic areas to which the government tries to attract private businesses by offering low taxes and other government support

${ }^{7}$ Centers that offer low businesses low-cost offices with basic services such as accounting, legal advice, and secretarial help
} 
periodicals with other peers and their professors. Thanks to this, their managerial skills are practiced and students become more confident in the entrepreneurship.

Universities should create forums for their students to realize their creativity, and nurture their desire to do business through activities such as writing business plans, generating new product ideas and concepts, identifying market opportunities, doing market surveys, and so on. These activities can help them apply what they learn in theory, make the most out of their creativeness and practice their managerial skills. To make these activities more effective, foreign students can also join the forum where English-majored students can take advantage of their language and intercultural skills.

Universities should maintain a good "academic-business link" where entrepreneurs, business practitioners, venture capital firms, and business angles in certain fields can share their experiences in starting up, inspire students, help assess and advise on EET programs and work as trainers in these programs. If possible, alumni who are entrepreneurs should be invited to mentor or coach the participants. Without this critical link, EET programs may stick to the theory only. Besides, the connection can equip academics with real-life evidence, which might be included in the EET programs later.

Universities should enhance research work through the internship and onsite/fact-finding visits to businesses where they can see real things that cannot be learnt at university. Doing research also helps them get rid of their concerns over entrepreneurship, explores new areas of ventures and helps them identify their own strength or talent. The successful business may inspire them or help them foster their desire for a start-up.

Universities should facilitate cross border faculty and research collaborations. This should be a widespread trend when enterprises tend to become multinationals through their expansion. The labor market then becomes more and more global; hence, people should learn to work globally. As a result, a panel of good teachers who can work and do research internationally are highly valued. Thanks to this, they 
can understand another part of the world better, which inspires their students with their achievements and understanding of the world's market and helps advise them on entrepreneurship better.

Quality entrepreneurship curricula are very critical in EET programs for students. Most entrepreneurship courses, materials, and research are borrowed from foreign countries, and they are normally modified to fit in the real condition of Vietnam. As a result, universities need a multidisciplinary panel of scholars to provide recommendations and a group of good entrepreneurship teachers, which makes sure that these entrepreneurship courses, materials, and research are of high quality.

\section{Conclusion}

EET programs have become a trend in universities in most parts of the world. Even though it is true that not all the participants can become entrepreneurs no matter how good EET programs are, it is worth inspiring students and nurturing their desire to start up a new enterprise when the unemployment rate all over the world has been higher and higher. In Vietnam, EET programs are mostly introduced as extracurricular activities by an in-university department or an independent organization. This should have been the subject of interest for scholars and academics to help generate jobs, create wealth and make most out of the workforce's creativity and innovation due to the competitive employment market. To make EET work, not only universities but also the national government should work together to give favorable contexts for entrepreneurs throughout the country. 


\section{References}

Bateman, ,. T. (1999). Management: Building competitive advantage (4th edition). The USA: McGraw-Hill.

Bich, T. T. (2008). Firm efficiency in a transitional economy. Asian Economic Journal, Vol.22 No1, 47-66.

Certro, S. \&. (2009). Modern concepts and skills management (11th edition). The USA: Prentice Hall.

Fane, L. (2012). Languages and entrepreneurship: A guide for students. The UK: Higher Education Academy.

Freed, A. F. \& Ehrlich, S. (2010). Why do you ask? The function of questions in institutional discourse. New York: Oxford University Press.

Ghillyer, A. (2009). Management: a real world approach. McGrawHill: The USA.

Hatten, T. (2014). Small business management: entrepreneurship and beyond. Canada: Cengage learning.

Heberer, T. \&. (n.d.). Private entrepreneurship and social change in transitional economies: the sociopolitical impact of private industry in Vietnam.

Hoang, V. a. (2009). The cultural dimensions of the Vietnamese private entrepreneurship. Journal of Entrepreneurship Development, Vol. VI, Nos 3\&4, 54-78.

Kuratko, D. F. (2009). Introduction to entrepreneurship (9th edition). Australia: Cengage learning.

Lantolf, J. P., \& Appel, G. (Eds.). (1994). Vygotskian approaches to second language research. Norwood: Ablex.

Macombs, B. L \& Whisler, J. S. (1997). The learner-centered classroom and school. San Francisco: Jossey-Bass. 
Napier, N. V. (2012). It takes two to tango: Entrepreneurship and creativity in trouble times - Vietnam 2012. Sociology Study, Vol.2, No9, 662-674.

Nickels, W. M. (2012). Understanding Business (10th edition). The USA: Mc Graw Hill Higher Education.

Paswan, A. \&. (2013). Vietnam and entrepreneurial enterprises: a Macromarketing perspective. Journal of Macromarketing, 32(1), 18-32.

Poon, J. P. (2012). Social capital and female entrepreneurship in rural regions: Evidence from Vietnam. Applied Geography, 35, 318315.

Rallis, S. F. (1995). Creating learner-centered schools: Dreams and practices. THEORY INTO PRACTICE, 34(4), 224-229.

Stokes, D. \&. (2010). Small business management and entrepreneurship (6th edition). China: cengage learning.

Swiekczek, W. F. (2013). Entrepreneurship orientation, uncertainty avoidance and firm performance: an analysis of Thai and Vietnam SMEs. The international journal of entrepreneurship and innovation, Vol.4, No.1, 46-58.

Thang, V. e. (2019). Cultural values, market institutions, and entrepreneurship potential: a comparative study of the US, Taiwan and Vietnam. Entrepreneurship 14(21).

Ur, P. (2012). A course in English language teaching. Cambridge: Cambridge University Press.

Valerio, e. a. (2014). Entrepreneurship Education and Training Programs around the world. Washington DC: The World Bank.

Wilson, K. (2008). Entrepreneurship and Higher Education. European Foundation for Entrepreneurship Research.

Worthington, I. \&. (2009). The business environment (6th edition). the UK: Pearson Education Limited. 